\title{
Social Help in Post-traumatic Stress Disorder
}

\section{J. Dacok (Jan Dacok)}

Pontifical Gregorian University, Italy

\section{Original Article}

\section{E-mail address:}

dacok@jezuiti.sk

\section{Reprint address:}

Jan Dacok

Pontifical Gregorian University

Piazza della Pilotta 4

00187 Rome

Italy

Source: Clinical Social Work and Health Intervention

Volume: 10

Issue: 2

Pages: $32-39$

Cited references: 16

\section{Reviewers:}

Roberto Cauda

Institute of Infectious Diseases, Catholic University of the Sacred Heart, Rome, Italy

Gabriela Lezcano

University of California, San Francisco, USA

\section{Key words:}

Trauma. Acute Stress Disorder. Post-traumatic Stress Disorder. Social and Ethical Principles. Prevention.

\section{Publisher:}

International Society of Applied Preventive Medicine i-gap

CSWHI 2019; 10(2): 32 - 39; DOI 10.22359/cswhi_10_2_05 @ 2019 Clinical Social Work and Health Intervention

\section{Abstract:}

The article presents the fundamental characteristics of trauma, acute stress disorder, and post-traumatic stress disorder, and describes the specific elements of post-traumatic stress disorder in childhood and adolescence. Consequently, it confirms the essential social and ethical principles involved, and with their help considers possibilities of providing social help and promoting prevention from the personalistic and Christian point of view. Children and adolescents, in particular, when exposed to traumatic and stressing events, respond better when they are 
supported by their own families or communities. It is very important that these stakeholders be encouraged and helped to accept such a vocation. It is essential to manifest solidarity and humanity to the afflicted, aiming to motivate them and provide them human, professional, social and spiritual accompaniment.

\section{Introduction}

This social study is based on a personalistic approach and highlights the dignity of the human being, its protection and respect, the building and support of its dignity (CIESKO, 2016) in any situation and puts the human person at the core of every single action. This kind of social help is intended to co-operate for the sake of individual health and social life. After introducing some subject-related terminological remarks, this article is intended to focus on the main features of acute stress disorders and post-traumatic ones with the specific elements of post-traumatic stress disorder in youth. It further re-affirms the basic ethical and social principles and, in their light, considers the possible actions and pre-empting measures to be taken by personalistic social operators.

\section{Some terminological remarks}

The word trauma is generally intended as "injury caused by a violent action, also in the psychological sector" (Zingarelli, 1990). In the field of medicine, trauma (from Greek $\tau \rho \alpha u ́ \mu \alpha$, "injury") indicates an "injury in the human body caused by any agent capable of a sudden, rapid and violent action". In psychology and psychoanalysis, it is intended as a "trouble in the psychic state caused by a very emotional event". In a figurative and extended sense, trauma is a "serious alteration of the normal psychic state of an individual, caused by sad, sorrowful and negative experiences and facts troubling and leading to disorientation" (TRECCANI, 2018 www.treccani.it/ vocabolario/trauma/). At first sight, trauma has many meanings and its causes can be diverse and multiple. O. Horowitz characterizes a serious trauma by the following eight psychological symptoms: “1) sorrow or sadness; 2) guilt for one's own anger; 3) fear for destructive attitudes; 4) survivor's guilt; 5) fear for victim's identification; 6) shame for feelings of impotence and void; 7) fear for a new traumatic experience; 8) deep anger for trauma's source" (Horowitz In GABBARD, 1995) A serious trauma causes profound and permanent changes to the physiological state, emotions, cognitive abilities and human memory (SCHREITER, 2018).

\section{Acute Stress Disorder}

The American Psychiatric Association includes the post-traumatic stress disorder (PTSD) among the disorders related to trauma and stressor-related events (American Psychiatric Association, 2013). Before talking about PTSD, it is necessary to give some hints on the acute stress disorder.

Among the most recurrent causes of acute stress disorders there are mainly the following: real or threatened death danger, rape and severe damage of organs/tissues. These causes concern witnessing or direct involvement in the traumatic event, involvement of close friends/relatives in the traumatic event or direct and repeated working exposure to traumatic events, such as war veterans, policemen, rescuers and paramedical professionals, etc. Acute stress 
disorders can be diagnosed only three days after traumatic events. Its typical symptoms can last from three days to one month and their triggering is strictly related to traumas. Their main symptoms for diagnosis are: intrusive thoughts; negative thoughts; dissociative symptoms; emotional numbing and avoidance of reminders of the trauma and incidental factors that may originate such feelings, thoughts or memories; hyperarousal symptoms (e.g., sleeping problems, irritability, physical or verbal aggression to people or objects, mental concentration problems (SCHREITER, 2018).

After one month, the acute stress disorder can gradually move towards PTSD, but it can also dissolve as a temporary reaction to the trauma stress. It is important to observe that nearly $50 \%$ of people hit by PTSD were exposed to acute stress disorder. Traumatic experiences like rape, aggression, mass-killing witnessing lead to acute stress disorders in nearly $25-50 \%$ of the subjects. For less than $20 \%$ of the examples, there are traumas that are not related to inter-personal assaults: road accidents (13-21\%), moderate brain damage from traumas $(14 \%)$, big fires (10\%), industrial accidents (6-12\%). Acute stress disorder affects women mainly. (For a detailed description of the diagnostic criteria, the diagnostic peculiarities and related ones, predominance, development, differential diagnosis and other relevant aspects of acute stress disorder, see American Psychiatric Association, 2013).

\section{Post-traumatic Stress Disorder}

Post-traumatic stress disorder signs in the adult population have been described for more than a century, but only in 1980 PTSD was recognized as a psychiatric disorder and included in the Diagnostic and Statistical Manual of Mental Disorders, Third Edition (DSM III). For example, in the USA there is a very high rate of adolescents and children exposed to traumas and violence Nearly $30 \%$ of 15 -year adolescents living in some areas of Chicago with high rate of criminal actions, have witnessed murders. More than $70 \%$ of them stated that they took part in serious aggressions (GARBARINO - VITIELLO, 2004). According to some pieces of research their percentage has reached $60.4 \%$. In the last few years, PTSD incidence among adolescents and children has even grown. Some pieces of research showed that nearly $6-10 \%$ of children and young people were affected by PTSD typical symptoms during their growth. Among the main causes leading to this disorder, there are: direct experience of physical or sexual harassment, community, school or home violence, car accidents or the like, severe diseases (cancer, severe burns), natural disasters (earthquakes, hurricanes) or disasters related to human activities, kidnapping, explosions, war or refugee camp conditions (Kaplan \& Sadock's, 2015).

Diagnostic criteria are the same for olderthan-6-year children, adolescent and adult people. As a matter of principle, PTSD development causes and cause exposure modalities are the very same, as in the above mentioned situations of acute stress disorders. It is relevant that symptoms last over one month. Among the negative thought and emotional alterations relating to the trauma (or traumas), there are: self-blaming or blaming on others and statements like: "We cannot trust anyone", "I am a bad person", etc. Furthermore, there are other symptoms such as: depersonalization, de-realization, helplessness, general loss of interest in life, separation from others, incautious or self-destructive behaviors. From a clinical point of view, there are unease or imbalance feelings in the social, working and other relevant contexts. It is important to re-affirm that neither toxic substances (like alcohol or 
drugs) nor pathologic conditions (epilepsy) can be held responsible for PTSD symptoms (American Psychiatric Association, 2013). PTSD is mainly characterized by typical symptoms caused by one or more traumatic experiences. The clinical pattern of this disorder is changeable: some signs relating to the symptom group described in the acute stress disorder can be predominant (such as fear, emotional or reaction-to-outside symptoms, negative thoughts, etc.). A combination of the various symptom groups is also possible (McNally, 2009).

\section{PTSD Specific Features in Youth}

In the USA the major incidence of traumatic events is between 16 and 20 years of age. Generally, PTSD development is more widespread among girls. As regards natural disasters, PTSD occurrence is similar for both sexes. According to some epidemiological studies, a percentage between $0.5 \%$ and $4 \%$ of young people between 9 and 17 years, suffered from PTSD with symptoms lasting three months. Children and young people exposed to chronic traumas (e.g. war, community splitting - migration, parent separation or divorce, possible abuse) show enhanced risk for PTSD evolution.

PTSD symptoms can appear at any age, even in the first year of life. They must persist one month at least. Children and adolescents may experience hyperactivity and obsessive reconstruction of traumatic elements. Children and adolescents tend to segregate traumatic experiences more than adults, and therefore may focus more on some of their elements while suppressing others (SCHREITER, 2018). PTSD symptoms cause anguish and serious detriment to important life activities. When the trauma-related symptoms have lasted for at least three days and then have disappeared within 30 days, we talk about acute PTSD. When PTSD has lasted for over three months, it is chronic PTSD and it could persist until six months after trauma exposure. In some children or adolescents, more moderate kinds of PTSD can last for over one or two years. Furthermore, in some cases and under serious conditions, PTSD symptoms can persist for many years, even decades (even more than 50 years!) and their spontaneous remission occurs only in a portion of these children and adolescents. Moreover, in sexually or physically abused children and adolescents (and later on in their sons or daughters) there were higher rates of depression and suicide attempts. As a result of this, it is of paramount importance for the future of those young people (KAPLAN \& SADOCK'S, 2015) to diagnose and treat PTSD timely.

\section{Basic Social and Ethical Principles}

They summarize the personalistic approach in the fields of social work and biomedicine (For a synthesis of the basic social and ethical principles, mainly see: SGRECCIA, 1991). Here we will try to show their contribution to avoid or mitigate traumatic and catastrophic causes and their aftermath.

\section{The common good by means of ev-} ery person's good - This principle aims at reaching everybody's good through every involved person's good. It respects and reflects the ontological value of people. In fact, it is not the society which shapes the human person, but, on the contrary, the person transcends the society and shapes it. Common good is not opposed to individual good, it does not put it aside, but includes it in the whole. People working in the fields of disasters and traumas, mainly in disaster medicine and social aid, are invited to take inspiration from the personalistic idea of the common good. 
The human life protection and respect principle - The human person is perceived as a spiritual being as well as a sexual body through which each appears and expresses itself. A person and their freedom can only be expressed by their body. The whole ontological richness of the human person is certainly not expressed just through their body and physical life, but they need to be respected, fostered and protected. Human life cannot be violated. Health and social relation promotion and protection belong to the principles of life defense, too (SCHREITER, 2018). Under the above mentioned human life protection principle, one's life cannot be exposed to risks or suppressed: especially the life of the most disadvantaged persons depending on other people's help and solidarity, must be preserved. The human body deserves respect since it is worthy; consequently, it cannot be exploited, but only given as a personal and mutual gift (FAGGIONI, 2010, see also: M.L. DI PIETRO, 1999).

The therapeutic principle ("the totality principle") - It justifies all invasive therapeutic-diagnostic procedures and surgical operations, mainly. Nonetheless, there are the following basic pre-requisites: the operation on physical life is admitted only when the person needs to be saved in its unity and totality; when the intervention concerns the damaged part or organ only; the operation is the only treatment chance and has a high percentage to be successful; it is necessary to inform the patient who must give his/her informed consent.

The freedom and responsibility principle - Human action is really "human", only when it is free. Only in this case, human action is also responsible. Freedom is typical of human actions that must be responsible. Freedom cannot justify one's or others' lives' suppression since freedom cannot exist without life. Freedom practice implies life from which freedom originates accordingly. Real freedom is responsible and takes care of others. Freedom and responsibility must go hand in hand and cannot be opposed.

\section{The subsidiarity and solidarity princi-} ple - It expresses the social and community aspects of the human being and humankind. At the same time, every community member is co-responsible for other people's good,. Other people's requirement or urgent need is an invitation, an obligation to help him/her. Thus, human dignity and its completion are perceived properly. Subsidiarity expresses creativity under normal conditions. International aid and co-operation are based on subsidiarity and solidarity principles (SCHREITER, 2018). These principles can enhance human action solidarity and responsibility in very difficult areas where there are the most helpless people. Basic ethical and social principles can become "a dialogue and co-operation bridge mainly for the safeguarding of human dignity" (FURIOSI, 2013).

The possible proposals - It is certainly not easy to propose possible solutions in such a complex field. What follows here is only intended to draw some tracks that could be approximately.

The pre-traumatic area includes a large variety of actions since it concerns all kinds of pre-empting measures: individually, in families, socially, nationally, internationally and globally. At an individual and family level ${ }^{1}$ (SMIDOVA, 2017)

The importance of pre-empting social measures is highlighted by Prof. PhDr. Maria Smidova, PhD., a Slovak professional operating in the field of social work training and tutoring. 
divided into three areas: pre-traumatic, peri-traumatic and post-traumatic. It is very important to prevent family imbalance, parent separation or death. As seen above, children and young people experiencing traumas or stressing events react in a better way when they are supported by their families or communities. At the same time, it is relevant: to assure safety in transportation and working conditions; justice in social and health policies; access needs to be granted to social and health operators; adequate treatment and social aid. Environment protection, flood and above all, war pre-emption play primary roles, too.

The peri-traumatic area is related to trauma "surrounding" context and time. Pre-emption should be targeted at trauma seriousness and aftermath mitigation. Regarding prevention in this field, it is necessary to take into consideration the fact that anniversaries and various events may trigger the traumatic experience again, despite the achieved recovery. This is caused by the emotions that the recovery process was unable to deal with and that are still present. The fact that the traumatic experience emerges again does not mean that the previous recovery process was ineffective or wrong. However, the trauma may be deep-rooted, causing such events to trigger old, negative and unpleasant feelings at any time. In the prevention process, it is therefore necessary to assure the victims of trauma that, if such recall happens, it does not mean it was a failure or their own personal fault (SCHREITER, 2018).

The Post-traumatic area mainly concerns help and most rapid trauma effect elimination, timely diagnosis and adequate therapy with social support, at all levels. Here, national, international and even global co-operation are very important. Such form of cooperation, including the above-mentioned factors, should also attempt to assure victims of trauma that they are fully-fledged human beings; worthy of love despite all the terrible events that have happened to them.

\section{Conclusion}

What we have examined has underlined the relevance of family and community roles that can support people affected by PTSD. Support (every kind of support), closeness and encouragement are important mainly in this context. Christian and human presence urges hope and orientation towards Him who is the source and guard of hope. People with religious faith, mainly Christians, can recover more easily ${ }^{2}$ because they can be supported by Him, in whom they trust. Thoroughly, he is God almighty, revealed by Jesus Christ, real God and real man. The essential thing is to express solidarity and humanity aiming at dedication, human, professional, social, and spiritual closeness; all this has a unique target: help the recovery of those in stress and trauma.

\footnotetext{
The specific process of trauma recovery enhanced by the Christian religion also in connection with the field of social work can be found, for example, in the studies of the American missionary Robert Schreiter, who created a concept of reconciliation, and, based on his years of working with individuals, groups and nations in various social and opinion systems that experienced very serious, stressful, traumatic and catastrophic events, he presents several ways to help them on their way to recovery. Cf. JASSO, J (2016) Recommendations for mutual relations between the Greek-Catholic Church and the Russian Orthodox Church on Ukraine's territory following the application of the reconciliation process based on Robert Schreiter's concept. p. 48-66; See also: Cf. SCHREITER, R (2017) The Distinctive characteristics of Christian Reconciliation relevant for current mission activities, p. 8-22; and Cf. SCHREITER, R (2016) Reconciliation as a mission model for the first half of the 21st century, p. 5-12.
} 


\section{References}

1. CIESKO P (2016) Analysis of selected social elements relevant for current mission activities from the perspective of a social study of the Church. In Acta Missiologica, 201610 (2) p. 35 - 47, 38 here ISSN: 13377515 (Print) ISSN: 2453-7160 (On-line).

2. ZINGARELLI N (1990) Il Nuovo Zingarelli. Dictionary of the Italian Language. Zanichelli, Bologna 1990, p. 2042.

3. TRECCANI Trauma. In Dictionary, www. treccani.it/vocabolario/trauma/ (Access: June 6th 2018).

4. SCHREITER R J (2018) Dealing with trauma and the healing of memories. In Acta Missiologica, 201812 (1) p. 7-16, here 8, 10, 12-13, 15 ISSN: 1337-7515 (Print) ISSN: 2453- 7160 (On-line).

5. HOROWITZ O (2009) In G. GABBARD G Psycho-dynamic Psychiatry. Raffaello Cortina Publ., Milano 1995, p. 258, quoted from: MAGNA P Traumatic Events. Road Accident Traumas. In Tredimensioni 3D, 6 (2009) p. 89-98, 91 here.

6. AMERICAN PSYCHIATRIC ASSOCIATION (2013) Diagnostic and Statistical Manual of Mental Disorders, Fifth Edition, $D S M-5^{T M}$, Arlington, VA 2013. For the purposes of this article, the Italian translation is used: AMERICAN PSYCHIATRIC ASSOCIATION (2014) Manuale diagnostico e statistico dei disturbi mentali, Quinta edizione, DSM-5, Italian version edited by M. Biondi, Raffaello Cortina Publisher, Milan, 2014. Cf. ID., p. 307, 325-332, 314316.

7. GARBARINO J - VITIELLO B (2004) Children. Mental Health Issues. In POST S G (Ed.), Encyclopaedia of Bioethics, Vol. I, Macmillan Reference USA, Gale Cengage Learning, Detroit - New York - San Francisco - New Haven, Conn - Waterville, Maine - London $2004^{3}$, p. 399-402, 400 here.
8. MCNALLY R J Post-traumatic Stress Disorder In KAPLAN \& SADOCK'S, (Eds.) Comprehensive Textbook of Psychiatry, Vol II, Wolters Kluwer, Philadelphia - Baltimore - New York - London - Buenos Aires - Hong Kong - Sydney - Tokyo 2009', p. 2650-2660.

9. KAPLAN \& SADOCK'S (2015) Synopsis of Psychiatry. Behavioral Sciences/Clinical Psychiatry. Wolters Kluwer, Philadelphia - Baltimore - New York - London - Buenos Aires - Hong Kong - Sydney - Tokyo $2015^{11}$, p. 1221.

10. SGRECCIA E (1991) Manuale di Bioetica. II. Aspetti medico-sociali, Vita e Pensiero, Milano 1991, p. 343-345.

11. FAGGIONI M P (2010) Sessualità matrimonio famiglia Centro editoriale dehoniano, Bologna 2010, p. 135-146. See also: M L DI PIETRO, L'educazione della sessualità e la procreazione responsabile. In SGRECCIA E - SPAGNOLO A G - M L DI PIETRO, (Eds.) Bioetica. Manuale per i Diplomi Universitari della Sanità, Vita e Pensiero, Milan 1999, p. 313-338, 321-323 here.

12. FURIOSI, M L (2013) Bioetica e Guerra. Parte etica In SEGRECCIA E. - TARANTINO, A. (Eds.) Enciclopedia di Bioetica e Scienza giuridica, Vol. VI, Edizioni Scientifiche Italiane, Naples - Rome 2013, p. 815822, 817 here.

13. SMIDOVA M (2017) Early intervention as an offered hand, Rhetos, Warszawa, 2017 mainly see p. 61-66.

14. JASSO J (2016) Recommendations for mutual relations between the Greek-Catholic Church and the Russian Orthodox Church on Ukraine's territory following the application of the reconciliation process based on Robert Schreiter's concept. In Acta Missiologica, 201610 (2) p. 48-66 ISSN: 13377515 (Print) ISSN: 2453-7160 (On-line). 
15. SCHREITER R (2017) The Distinctive characteristics of Christian Reconciliation relevant for current mission activities. In Acta Missiologica, 201711 (1) 8-22 ISSN: 1337-7515 (Print) ISSN: 2453-7160 (Online).
16. SCHREITER R (2016) Reconciliation as a mission model for the first half of the 21st century. In Acta Missiologica, 201610 (1) 5-12 ISSN: 1337-7515 (Print) ISSN: 24537160 (On-line). 